http://ngtt.journals.ac.za

Ferrari, Silvio

President ICLARS (International Consortium for Law and Religion Studies)

\title{
Religion, Christianity and Civil Society
}

\section{Civil SOciety}

Civil society is a relatively modern concept. It was born at the end of the XVIII century and it is employed to define a sphere of human activities that presents peculiar features (Edwards 2009). Philosophers and lawyers make recourse to this concept to explain that every individual spends his life within a network of social relations that can be classified in four areas: the family, the State, the market and, finally, the civil society. Free and voluntary are the adjectives characterizing the relations that take place within civil society: associations, trade unions, political parties, non-profit organizations, religiously oriented schools, social movements, and so on, are the actors that populate this area of human life. They offer individuals the opportunity to develop together projects of life and social organization that can be reproduced on a larger scale as a model for organization of the broader social community. In other words, civil society is the space where, through particular experiences, the common good is pursued, and the institutions of civil society are the places where individuals develop and test the principles and convictions that guide their actions as citizens. This process can occur only in a context of freedom, where associations that have different aims, schools that are inspired to different value systems, political parties with different programs can coexist and interact. This explains why civil society tends to flourish more fully in democratic than in authoritarian or totalitarian States. As a matter of fact, civil society movements like Solidarnosc in Poland and the antiapartheid movement in South Africa played a decisive role in the fall of the Communist or racist regimes that were in power in those countries.

\section{The SIGNIFICANCE OF CIVIL SOCIETY}

Civil society therefore requires liberty, with all the advantages and at the same time with all the risks that liberty always entails: it is an open space, that can be filled with good experiences as well as bad ones. Why then does civil society deserve to be defended and expanded? What does it deliver in exchange of the dangers it involves? Basically, civil society can generate a social capital constituted by three fundamental civic virtues: it teaches individuals to live in a committed, responsible and trustful way (Putnam, Leonardi, Nanetti, 1994. Obviously it is possible that some associations, social movements, political parties foster intolerance and extremism instead of trust and responsibility: on this point see infra, par. 4). Each of us is ready to volunteer time and effort to the associations of which he is a member, to the political projects in which he believes, to the schools his children attend: each of us feels responsible for those ventures in which he is involved and, in order to make them flourish, is ready to establish relations of trust and cooperation with other individuals who share the same ideals. This education to responsibility, commitment and trust that takes place in the institutions of civil society is indispensable to form good citizens, who are able to reproduce these same civic virtues when they act as members of the larger State community: therefore, the existence of a vital civil society can offer a decisive contribution to the common good of 
the State by providing both values and attitudes that foster social commitment and cohesion without giving up plurality and differences.

To sum up what I have said, I shall refer to an American lawyer, Robert Cover. According to him, any society is based on balance between two forces: the force that creates the world and the force that maintains it. Cover says we live in a space inhabited by many normative worlds, each of them characterized by its own set of values and rules. These normative worlds are the social groups (religious, cultural, political groups and so on) that are capable of generating new legal values and meanings through the personal commitment of their members: by applying their will to transform the extant state of affairs according to their visions of alternative futures, they create worlds governed by a new law. But these normative worlds, if are left to themselves, can become sectarian, violent and dissociative. Therefore the coexistence of different legal worlds requires a system-maintaining force. The modern State can offer it, provided it understands that it has not the task to create new legal values but to foster the birth and development of the normative worlds where these values take shape (Cover 1983, 4-68).

In conclusion the institutions of civil society play a generative role both for the values that support the State's laws and for the civic virtues that support the State's political activity. A State based on principles of freedom and democracy cannot properly claim to generate the values that citizens are called to share nor the attitudes that should support their participation in the life of the polis: for both of them the State can rely on civil society. Therefore the State's contribution to the common good is not in the field of creation but in that of conservation and it performs this task by providing a legal framework where different projects of common good can peacefully coexist.

\section{ReLigions AND CIVIL SOCIETY}

Religions offer a peculiar element to the civil society debate, that is, the conviction that man is repository of a truth given by God. This conviction is highly significant to the development of a sound civil society. It has already been said that civil society can create commitment, personal responsibility and mutual trust: but what is the foundation of these virtues, what persuades men to behave in a responsible and committed way? Religions -or at least those religions that are founded on divine revelation- answer that this attitude is ultimately rooted in man's responsibility towards God: the commitment to build the common good, through personal responsibility and a relation of trust with other persons, is generated by recognition of the truth that has been given by God to human beings.

This approach to civil society, typical of the monotheistic religions, gives a sound and stable basis to the research of the common good and connects it to some non negotiable principles that, being rooted in divine revelation, transcend social consensus and political expediency. At the same time this approach raises the problem of harmonizing truth and liberty. If the central feature of civil society is the free research of the common good through a committed participation in particular experiences, how can this research be shared by those who know they possess the truth?

There are two answers to this question. The first is a theological answer that goes beyond the scope of my presentation. Therefore I shall deal with it very briefly. In a religious perspective, man is not the master of the truth he proclaims nor the craftsman of its success among men. Being in the service of truth and affirming it without hesitation is all that can be expected by 
man: on the contrary, trying to impose the truth denies that its recognition, although in need of human cooperation, depends on God's will. In this perspective I can profess unconditionally the truth of my faith and publicly witness the events that changed my life and my world view without the need to affirm the supremacy of my religion and the obligation of everybody to accept it. It seems to me that this answer has a sound foundation in the theological and legal tradition of different monotheistic religions (Williams 2008, 249-54).

The second answer is too complex to be considered in relation to every religion. Therefore I shall give it in relation to just one of them, Christianity.

\section{Christianity and Civil SOCiety}

Religion is first of all a personal relationship between God and man: this is the starting point for analyzing the relationship between Christianity and civil society. This principle is the novelty brought by Christianity into the Greco-Roman world, where religion had more a national and family dimension than a personal one: and this is also what makes Christianity different from Judaism, which conceives religion as a covenant between God and one people. In the Jewish and Roman societies, where in different forms the collective dimension of religion prevailed, Christianity affirms a new principle: religion is the choice of conscience of a person who, questioned by Jesus Christ's message, decides to answer yes. Obviously in Christianity too there is a communitarian dimension, that manifests the solidarity -more exactly, the communionof the faithful who share faith in the same God. But this dimension is based on a personal assent that questions the responsibility of each individual. In other words, persons are not born Christian but become Christian: and they become so not because they are members of a community, a people or a family, but because of a personal choice.

The accent placed on the personal dimension of the religious experience paved the way for the birth of a new right, that was unknown in the ancient world: the right of religious liberty. According to Christian doctrine nobody -the State, the community and even the family-can take the place of the individual in deciding a matter of conscience: therefore every person must be completely free to choose his religion (and also to change or abandon it), because an authentic religious experience cannot exist outside a state of liberty. This right to religious freedom is absolute, that is it is due to every person (not only to Christians) by virtue of his being a person. Moreover, it is unlimited, that is no human power can restrict the right of an individual to choose the religion he deems to be the true one. Sadly, this right is infringed in many parts of the world and the faithful of many religions -Christianity included- are subjected to persecution or, because of their religion, do not enjoy civil and political rights on equal footing with other citizens.

Religious freedom has not always been respected in the history of the Christian countries nor in the teachings and actions of some representatives of the Church itself: John Paul II publicly asked forgiveness for these sins. But the principle that the religious faith requires liberty was never forgotten in the Christian tradition and it was fully reinstated on the occasion of the Vatican II Council by affirming that religious liberty is a right that "has its foundation in the very dignity of the human person" (Dignitatis Humanae, n. 2). The significance of this statement is evident: as a German lawyer, Ernst Wolfgang Böckenförde, put it, religious freedom "that previously was a concession, now becomes a commandment, an obligation that is rooted in the Christian faith itself and in its correlated image of man". In this way truth and freedom can be reconciled: if "religious freedom is inherent to the truth itself of Christianity", affirming

- 60 - NGTT Deel 54 Supplementum 4, 2013 
that the Gospel is the truth for every man implies affirming "the religious freedom of every man, including those who do not have any faith or have and practice a faith that is different from mine or, simply, have given up their faith" (Böckenförde, 2004, 722). At this point the contradiction between truth and liberty reveals that it is only an apparent contradiction: it is possible to fully participate in the free and open debate of civil society without giving up or marginalizing the claim that Christianity is the true religion, as the freedom of non-Christians is coessential with this claim.

Once it is clear that taking part in the civil society debate does not imply a relativisation of truth, it is possible to underline two other reasons for looking to civil society with sympathy.

First of all, the recognition that a sound State requires a sound civil society strengthens the subsidiarity principle, according to which the State does not have to take on those tasks that can be performed equally well by the institutions of civil society, for example by associations or social movements. From the perspective of the subsidiarity principle, the State has basically the task of providing the legal context and the economic support for developing the civil society initiatives. Only when the needs to be faced are so huge that civil society alone cannot cope with them (one can think, for example, of the need to put in place a national health service), is the State entitled to act on its own. In this way State power is maintained within its proper dimensions, avoiding its hypertrophic and potentially dangerous over-development.

Second, the central role recognized to civil society engages the Christian faithful to take on its responsibilities in the social and political fields. The distinction between religion and politics, Church and State, that is traditional in Christian thought, has sometimes been misunderstood and interpreted as something that limits the responsibility of Christians to the spiritual affairs, leaving the temporal and political world outside the area of concern of the faithful. I think the opposite is true. For centuries the Christian community has sought security in the confessional character of the State: State laws supporting Christianity and affirming the Christian character of the State were misunderstood as the guarantee of the Christian character of society as well. This mistake had a negative impact on the vitality of the Christian community, as the responsibility of transforming society according to Christian values was regarded more as a duty of the State than the mission of each Christian. The decline of State confessionism and the principle that State institutions cannot become the instruments of any religion -including the one professed by the majority of the citizens- has encouraged Christians to take on the responsibility to witness the values they uphold in the places where people live, in schools, families, workplaces, that is in civil society.

\section{Civil society, State, And Religion: A delicate balance}

One last and problematic feature of civil society still has to be taken into consideration before concluding my presentation. It would be naïve to believe that civil society, simply by virtue of its being a free and open society, is always conducive to the common good. The projects and initiatives that are generated by civil society can pursue the interest of the few instead of justice, create divisions instead of solidarity, intolerance instead of mutual understanding. Faced with this ambiguity that is inherent in civil society, the question is how to sort its products so that what is helpful for common good can be separated from what is harmful. But who can perform this job and what are the criteria that can guide this selection?

This problem can be summarized in the following terms: on the one hand there is civil society, that is the place where projects and proposals for the organization of social coexistence are 
freely elaborated; on the other hand there is the State, that is the entity that selects some of these projects and puts them at the foundation of its laws. How the State can perform this task of filtering and selecting without destroying liberty, which is essential for the sound development of civil society and, on the other hand, without falling into an anarchy of competing values that is incompatible with the idea of common good?

Some think that this dilemma has no solution. Böckenförde for example wrote that "the liberal and secular State lives on the base of presuppositions whose truth it is unable to guarantee" (Böckenförde 1991, 112). I think that this statement is correct only in part. First of all, civil society is not totally free, does not live in a vacuum, but operates within a framework defined by rules that grant respect for some fundamental and non negotiable principles upon which every State is based (nobody could appeal to the liberty of civil society to support, for example, slavery or human sacrifices). Second, within this large framework there are further rules that are rooted in the tradition and culture of each national community. They reflect the identity of every community and shape accordingly its relations and institutions, from the family to the work place, from the relations between man and woman to those between citizen and State. They provide a more narrow framework within which the civil society is contained, a framework that exists in all the civilizations of our world but that has different characteristics in each of them as it is the outcome of different histories and cultures. In other words, the State is not an empty container that can be filled with whatever content: on the contrary it has a memory and a history that provide guidance in selecting the inputs coming from civil society. This State framework is far from being immutable, as it is continuously in transformation under the inputs of civil society; but at the same time it is far from being neutral, as it is made by people with a culture and an identity that has taken shape in history and that inevitably influence court decisions, Parliament laws and their application by public administration ${ }^{1}$.

From history we have learnt that the balanced development of any social community requires that two equally grave dangers be avoided: the revolutionary utopian effort to get rid of tradition and the conservative one to crystallize it, irrespective of the changes that continuously take place within any social group. Both approaches have proven to be wrong. The identity of a social community is not an immutable genetic code, that is given once for all and cannot be changed for eternity, but an inheritance that should be enlarged through exchange with the other identities, old and new, that inhabit the world: understanding this fact is the way to approach in a correct way the relation between civil society and State or, to make use once more of Cover's language, between the forces that create and those that maintain the world.

In this perspective a State that is attentive to the common good cannot but recognize religion's full liberty to take part, within civil society, in the formation of the public ethos that is indispensible to the life of the State itself. For many decades, particularly in Europe, religions have been confined to private space and basically excluded from public debate. Today things are different and religions have to face new responsibilities and new opportunities: both the first and the second require a sound relation between religion and civil society in contemporary world.

\footnotetext{
1 Neutrality, if intended as the absence of any distinctive quality or characteristic of the State, is a chimera: State institutions cannot be severed from society and their activity is inevitably influenced by the history, culture, belief of the people they represent. State neutrality makes sense only if it is intended as the conscious effort of State institutions to pursue an impartial and well balanced policy towards the different groups and organization that constitute the civil society.
} 


\section{BiBLIOGRAPHY}

Ernst Wolfgang Böckenförde, Responsabilità della Chiesa nel mondo d'oggi, in II Regno-attualità, 20/2004

Ernst Wolfgang Böckenförde , Lo stato secolarizzato e i suoi valori, in II Regno-attualità, 18/2007

Ernst Wolfgang Böckenförde, Die Entstehung des Staates als Vorgang der Saekularisation [1967] in Recht, Staat, Freiheit, Suhrkamp, Frankfurt a. M., 1991

Robert Cover, Nomos and Narrative, in Harvard Law Review, 97, 1983

Michael Edwards, Civil Society, Cambridge, Polity Press, 2009

Robert D. Putnam, Robert Leonardi, Raffaella Y. Nanetti, Making Democracy Work: Civic Traditions in Modern Italy, Princeton, Princeton University Press, 1994

Rowan Williams, Faith communities in a civil society. Christian Perspectives, in Islam and Christian-Muslim Relations, 19, 3, July 2008 